\title{
Sclerosing Angiomatoid Nodular Transformation of the Spleen: An Uncommon Cause of Abdominal Pain
}

Euroasian Journal of Hepato-Gastroenterology (2020): 10.5005/jp-journals-10018-1319

In the article, "Sclerosing Angiomatoid Nodular Transformation of the Spleen: An Uncommon Cause of Abdominal Pain", which appeared in the pages 89-91, Issue 7, Vol. 1 of Euroasian Journal of Hepato-Gastroenterology the third author name is incorrectly written as "Göhan Akkurt" instead of "Gökhan Akkurt".

These have now been corrected and reposted online.

DOI: 10.5005/jp-journals-10018-1221

(0) The Author(s). 2020 Open Access This article is distributed under the terms of the Creative Commons Attribution 4.0 International License (https://creativecommons. org/licenses/by-nc/4.0/), which permits unrestricted use, distribution, and non-commercial reproduction in any medium, provided you give appropriate credit to the original author(s) and the source, provide a link to the Creative Commons license, and indicate if changes were made. The Creative Commons Public Domain Dedication waiver (http://creativecommons.org/publicdomain/zero/1.0/) applies to the data made available in this article, unless otherwise stated. 